\title{
ANALISIS KINERJA USAHATANI PERKEBUNAN KELAPA SAWIT RAKYAT MELALUI POLA KEMITRAAN DI PROVINSI KALIMANTAN TENGAH
}

\author{
Suharno ${ }^{1}$, Yuprin A.D., dan Betrixia Barbara \\ Tirtayasa Palangkaraya Institute for Land and Agricultural Research (PILAR) \\ Fakultas Pertanian, Universitas Palangka Raya \\ e-mail : 1)suharno_unpar@yahoo.com
}

\begin{abstract}
There are three models of partnership in the development of smallholders plantation of palm oil in Center of Kalimantan Province, those are: (1) inti-plasma model that is managed by cooperative; (2) inti-plasma model that is managed by company; (3) inti-plasma model that is managed by individual farmers. This research aims to find the best partnership model amongst them. This research has been done in Kotawaringin Barat District for the first and the third type of models and in Katingan District for the second type. Collecting data and informations was done by Focus Group Discussion (FGD) and interviewed to the farmer respondents. A random sampling of 30 farmers was chosen for the first and the second models. For the second model, all of the farmers who follow the program as many as 20 farmers was chosen as this research respondent. The research found that the first type of those models is the best amongst of the partnership models because of following reasons: (1) highest productivity, about 20 tonnes FFB/ha/year; (2) highest farmer income about Rp 15,682,711/ha/year; (3) business risks are shared by all of the cooperative members; (4) there is guarantee of the input supply and marketing of farming yied from company as a business partner; (5) farmers have some opportunities to increase their household income as company workers or through the other activities. This research recommends to the Government of Kalimantan Tengah Province to oblige the plantation companies to implement an inti-palsma partnership model that is managed by cooperative for whom obligation to develop about $20 \%$ of their plantation area for smallholders.
\end{abstract}

Keywords: palm oil, smallholder, partnership, farming performance.

\section{PENDAHULUAN}

Struktur perekonomian Provinsi Kalimantan Tengah masih didominasi oleh sektor pertanian, dimana kontribusi sektor pertanian terhadap Produk Domestik Regional Bruto (PDRB) pada tahun 2012 sebesar 27,99\%. Penyumbang terbesar terhadap PDRB dari sektor pertanian tersebut berasal dari sub sektor perkebunan, yaitu sebesar 12,36\% dari total PDRB (BPS Provinsi Kalimantan Tengah, 2013).

Tanaman perkebunan di Provinsi Kalimantan Tengah didominasi oleh perkebunan kelapa sawit. Total luas tanaman perkebunan kelapa sawit pada tahun 2013 adalah sebesar 1.168.451 ha dan diperkirakan pada tahun 2014 sebesar 1.187.181 ha. Luas perkebunan kelapa sawit rakyat pada tahun 2013 sebesar 181.136 ha dan pada tahun 2014 diperkirakan sebesar 181.379 ha, yang melibatkan sekitar 85.000 kepala keluarga petani pekebun (BPS, 2014).

Secara garis besar ada dua bentuk pengembangan perkebunan kelapa sawit rakyat di daerah ini, yaitu perkebunan kelapa sawit rakyat yang dikelola oleh masyarakat secara mendiri/swadaya dan perkebunan kelapa sawit rakyat yang dikelola melalui model kemitraan.

Ada tiga model kemitraan yang berkembang, yaitu (1) model kemitraan intiplasma yang dikelola oleh koperasi; (2) model kemitraan inti-plasma yang dikelola oleh perusahaan inti; dan (3) model kemitraan intiplasma yang dikelola oleh petani secara individu.

Permasalahan utama yang dihadapi pada perkebunan kelapa sawit rakyat adalah rendahnya produktivitas tanaman yang merupakan akibat dari praktik pengelolaan perkebunan yang kurang baik. Hal 
disebabkan oleh kurangnya pengetahuan dan kemampuan teknis usahatani, dan kurangnya modal yang dikuasi petani. Menurut hasil kajian Institut Pertanian Bogor (2012) terdapat kesenjangan produktivitas yang relatif tinggi antara perkebunan kelapa sawit rakyat dengan perkebunan besar swasta, yaitu berkisar antara $41 \%-64 \%$ dari produktivitas perkebunan yang mencapai 7-20 ton TBS/ha/tahun. Hasil penelitian tersebut juga menunjukkan bahwa petani kecil mandiri kurang produktif secara signifikan dibanding petani kecil yang bekerja dalam kemitraan dengan perusahaan inti.

Berdasarkan permasalahan di atas, maka perlu dikaji suatu model bisnis perkebunan kelapa sawit rakyat melalui model kemitraan yang memberikan pendapatan terbesar dan risiko terendah bagi para petani.

Tujuan dari penelitian ini adalah untuk membandingkan dan mencari model kemitraan terbaik diantara ketiga model kemitraan tersebut, agar dapat diberikan saran atau rekomendasi yang tepat kepada Pemeperintah Provinsi Kalimantan Tengah dalam rangka pengembangan perkebunan kelapa sawit rakyat di daerah ini.

\section{METODE PENELITIAN}

Penelitian ini merupakan penelitian survei, dimana data yang dikumpulkan diperoleh dari sampel responden terpilih, kecuali untuk model kemitraan inti-plasma yang dikelola oleh petani secara individu, dimana petani respondenya adalah seluruh petani yang mengituki program tersebut, karena jumlahnya terbatas.

Penelitian dilaksanakan pada tahun 2014, dimana pengumpulan data di lapangan dilaksanakan pada bulan Juli sampai September 2014, berlokasi di Kabupaten Kotawaringin Barat untuk model kemitraan inti-plasma yang dikelola oleh koperasi (Model I), tepatnya pada Koperasi Karya Tani di Kecamatan Pangkalan Lada, dengan perusahaan inti adalah PT. Medco, dan model kemitraan inti-plasma yang dikelola oleh petani secara individu (Model III) berlokasi di
Kecamatan Pangkalan Banteng, dengan perusahaan inti adalah PT. Astra. Sedangkan untuk model kemitraan yang dikelola oleh perusahaan inti (Model II), lokasi penelitian di Kecamatan Katingan Hulu Kabupaten Katingan dengan perusahaan inti PT. BW.

Pengumpulan data dan informasi di lapangan dilakukan melalui Focused Group Discussion (FGD) dengan para pemimpin dan tokoh masyarakat setempat dan wawancara secara langsung dengan petani responden. Untuk kepentingan analisis kinerja usahataninya, maka petani yang dipilih sebagai sampel responden adalah petani yang kebunnya sudah menghasikan, yaitu masingmasing untuk kemitraan Model I dan Model II sebanyak 30 orang petani yang dipilih secara acak (random sampling) dari seluruh petani yang memenuhi kriteria di atas. Sedangkan untuk model III, yaitu kemitraan inti-plasma yang dikelola oleh petani secara individu, karena jumlah petani yang mengikuti program tersebut terbatas hanya sebanyak 20 orang petani, maka seluruh petani tersebut ditetapkan sebagai sebagai responden dalam penelitian ini.

Analisis kualitatif dilakukan untuk memperoleh gambaran umum model kemitraan dalam pengelolaan perkebunan kelapa sawit rakyat dengan perusahaan besar sebagai mitra (inti), dan pengkajian pengelolaan risiko. Sedangkan analisis kuantitatif ditujukan untuk analisis finansial yang meliputi penerimaan, biaya dan pendapatan petani.

\section{HASIL PENELITIAN DAN PEMBAHASAN \\ DESKRIPSI MODEL KEMITRAAN}

\section{Kemitraan Inti-Plasma yang Dikelola oleh Koperasi}

- Koperasi dikelola sebagai sebuah entitas produksi, setiap anggota atau pemilik lahan berkontribusi dan mendapat keuntungan dari seluruh kebun yang dikelola oleh koperasi, tidak hanya dari luas lahan miliknya. 
- Anggota koperasi bekerja sebagai petani profesional, bertanggung jawab atas pemeliharaan dan panen untuk seluruh area perkebunan, tidak terbatas pada lahan miliknya, dan dibayar sesuai dengan tingkat upah yang berlaku.

- Pembangunan kebun didanai melalui Kredit Koperasi Primer untuk Anggota (KKPA), yang disalurkan melalui bank komersial dengan masa tenggang (grass period) selama 4 tahun.

- Selama kredit belum lunas, pembagian hasil panen adalah $70 \%$ untuk petani (melalui koperasi) dan 30\% untuk perusahaan inti sebagai angsuran kredit. Keuntungan bersih setelah dipotong biaya operasional dan fee untuk koperasi (sebesar $4 \%$ ), dibagikan merata kepada seluruh anggota setiap bulan.

- Koperasi bertanggung jawab atas seluruh kegiatan pemeliharaan kebun, panen, sampai penjualan hasil.

\section{Kemitraan Inti-Plasma yang Dikelola oleh Perusahaan Inti}

- Setelah mendapat Surat Adat/Surat Keterangan Tanah (SKT) dari pemimpin adat/kepala desa, petani menyerahkan lahan dan pengelolaan kebunnya kepada perusahaan inti.

- Ada koperasi, tetapi hanya untuk kepentingan finansial, hanya dalam distribusi pendapatan dari perusahaan kepada petani.

- Pemberian modal dari bank dikelola sepenuhnya oleh perusahaaan inti. Seluruh biaya pembangunan dan operasional kebun petani (plasma) dikelola oleh perusahaan inti.

- Selama masa pembayaran hutang, petani plasma hanya mendapat $20 \%$ dari nilai panen yang dihasilkan. Setelah pelunasan hutang, 55\% dari nilai yang dihasilkan dibayarkan kepada petani plasma.

\section{Kemitraan Inti-Plasma yang Dikelola oleh Petani Secara Individual}

- Petani yang memiliki lahan bergabung untuk membentuk kemitraan dengan perusahaan. Perusahaan inti menentukan minimal 10 petani dalam satu kelompok. Setiap petani bertanggung jawab untuk mengelola kebun miliknya sendiri.

- Pembangunan kebun petani dibiayai oleh perusahaan inti dan diperhitungkan sebagai hutang/kredit petani yang akan dibayar kembali melalui pemotongan nilai penjualan hasil ketika kebunnya sudah menghasilkan.

- Pemeliharaan dan pembiayaan kebun sepenuhnya menjadi tanggung jawab petani secara inividu.

- Petani dibayar 70\% dari nilai penjualan TBS ketika dalam masa pelunasan kredit. Ketika sudah lunas, petani menerima pembayaran $100 \%$ dari penjualan produksinya.

- Terdapat kewajiban secara kontrak bagi petani plasma untuk menjual produksi TBS-nya kepada perusahaan inti.

\section{KERAGAAN USAHATANI}

Terdapat perbedaan dalam keragaan usahatani dianatara ketiga model kemitraan perkebunan kelapa sawit rakyat tersebut yang disebabkan oleh berbagai faktor seperti: umur tanaman, pemeliharaan kebun, dan penggunaan input, yang diperkirakan berdampak pada perbedaan produktivitas tanaman yang sangat mencolok, seperti terlihat pada Tabel 1.

Pada Tabel 1 terlihat bahwa dilihat dari rata-rata luas lahan per petani, pada kemitraan yang dikelola oleh koperasi paling kecil, yaitu hanya seluas 1,98 ha. Sebenarnya rata-rata luas lahan tersebut adalah 2.0 ha per petani, tetapi karena dari seluruh luas lahan yang dikelola koperasi seluas 1.030 ha dengan jumlah anggota sebanyak 515 orang, terdapat lahan seluas 12 ha yang berstatus sengketa dan dikeluarkan dari pengelolaan koperasi, sehingga total lahan yang dikelola koperasi seluas 1.012 ha yang dibagi rata untuk semua anggota, sehingga rata-rata luas lahan per anggota menjadi seluas 1,98 ha. 
Tabel 1. Keragaan Usahatani Perkebunan Kelapa Sawit Rakyat pada Ketiga Model Kemitraan di Provinsi Kalimantan Tengah, 2014.

\begin{tabular}{|l|c|c|c|c|}
\multicolumn{1}{|c|}{ Model Kemitraan } & $\begin{array}{c}\text { Jumlah } \\
\text { Petani sampel } \\
\text { (orang) }\end{array}$ & $\begin{array}{c}\text { Rata-rata luas } \\
\text { lahan/ petani } \\
\text { (ha) }\end{array}$ & $\begin{array}{c}\text { Umur } \\
\text { tanaman } \\
\text { (tahun) }\end{array}$ & $\begin{array}{c}\text { Produktivitas } \\
\text { TBS (ton/ha/ } \\
\text { tahun) }\end{array}$ \\
\hline Dikelola oleh Koperasi & 30 & 1,98 & 16 & 20,0 \\
\hline Dikelola oleh Perusahaan & 30 & 3,01 & 17 & 18,0 \\
\hline Individual & 20 & 4,45 & 6 & 11,8
\end{tabular}

Pada model kemitraan yang dikelola oleh perusahaan inti rata-rata luas lahan per petani sebesar 3,01 ha. Perusahaan inti tidak menetapkan batasan luas lahan yang dikuasai petani yang diserahkan kepada perusahaan, jadi masing-masing luas lahan petani berbeda-beda.

Pada model kemitraan yang dikelola oleh petani secara individual, rata-rata luas lahan petani paling besar mencapai 4,45 ha. Berdasarkan hasil diskusi dalam forum FGD diketahui bahwa pada awal pengembangan model kemitraan ini pada tahun 2007 hanya terdapat sebanyak 20 orang petani yang mempunyai lahan untuk diikutsertakan dalam program tersebut, yang pada umumnya merupakan petani-petani yang termasuk petani cukup kaya dan masih mempunyai lahan cukup luas.

Dari segi produktivitas dalam bentuk tandan buah segar (TBS), terlihat bahwa produktivitas perkebuan kelapa sawit rakyat model kemitraan yang dikelola oleh koperasi, produktivitasnya paling besar yaitu mencapai 20,0 ton/ha/tahun. Bila merujuk pada hasil penelitian Institut Pertanian Bogor (2012) besarnya produktivitas perkebunan rakyat ini sudah termasuk kategori ideal karena sudah menyamai rata-rata produktivitas perkebunan besar.

Pada model kemitraan yang dikelola oleh perusahaan inti, produktivitas rata-rata sebesar 18,0 ton TBS/ha/tahun, lebih rendah dibanding model kemitraan yang dikelola oleh koperasi.

Pada model kemitraan yang dikelola oleh petani secara individu, produktivitasnya paling rendah hanya sebesar 11,8 ton TBS/ha/tahun. Hal ini kemungkinan disebabkan oleh pengelolaan kebun yang kurang baik dan umur tanaman yang masih relatif muda, meskipun untuk varieras bibit unggul tertentu dalam kondisi ideal, pada umur 6 tahun tersebut tanaman sudah memasuki masa produksi maksimal dan stabil.

Menurut Yahya dan Basyaruddin (2015) salah satu kondisi dan permasalahan yang dihadapi petani kelapa sawit mandiri, kebanyakan petani belum sepenuhnya menerapkan praktik pertanian yang baik (good agricultural practice/GAP) dan praktik pengelolaan kebun yang baik (good management practice/GMP)

\section{PENDAPATAN PETANI}

Hasil analisis pendapatan petani seperti terlihat pada Tabel 2, menunjukkan bahwa meskipun produksi per hektar pada model kemitraan yang dikelola oleh koperasi lebih tinggi dibanding produksi per hektar pada kemitraan yang dikelola oleh perusahaan inti, namun karena harga TBS yang diterima oleh koperasi lebih rendah, maka penerimaan yang diterima oleh koperasi juga lebih rendah. Sebaliknya biaya operasional per hektar yang dikeluarkan oleh koperasi lebih tinggi dibanding biaya operasional yang dikelola oleh perusahaan inti, maka laba operasional per hektar pada kemitraan yang dikelola oleh koperasi relatif lebih rendah dibanding laba operasional pada kemitraan yang dikelola oleh perusahaan inti. Demikian pula pula margin keuntungan yang diperoleh pada kemitraan melalui koperasi sebesar 67,30\% lebih rendah dibanding margin keuntungan pada kemitraan melalui perusahaan inti sebesar $85,63 \%$. 
Tabel 2. Pendapatan Petani Perkebunan Kepala Sawit Rakyat pada Tiga Model Kemitraan di Provinsi Kalimantan Tengah 2014

\begin{tabular}{|c|c|c|c|}
\hline Item Pendapatan & $\begin{array}{c}\text { Kemitraan } \\
\text { Dikelola oleh } \\
\text { Koperasi }\end{array}$ & $\begin{array}{c}\text { Kemitraan } \\
\text { Dikelola oleh } \\
\text { Perusahaan Inti }\end{array}$ & $\begin{array}{c}\text { Kemitraan } \\
\text { Dikelola oleh } \\
\text { Petani Individual }\end{array}$ \\
\hline Produksi/ha/tahun (ton TBS) & 20,0 & 18,0 & 11,8 \\
\hline Harga jual TBS/kg (Rp) & $1.216,33$ & $1.393,89$ & $1.234,02$ \\
\hline Penerimaan/ha/tahun (Rp) & 24.326 .683 & 25.090 .088 & 14.561 .407 \\
\hline $\begin{array}{l}\text { Biaya operasional/ } \\
\text { ha/tahun }(\mathrm{Rp})\end{array}$ & 7.955 .527 & 3.605 .544 & 10.799 .286 \\
\hline Laba operasional/ha/tahun (Rp) & 16.371 .156 & 21.484 .544 & 3.762 .121 \\
\hline Margin Keuntungan (\%) & 67,30 & 85,63 & 25,84 \\
\hline $\begin{array}{l}\text { Bagian Pendapatan } \\
\text { petani/ha/tahun (Rp) }\end{array}$ & $15.682 .711^{*}$ & $13.799 .548^{* *}$ & 3.762 .121 \\
\hline $\begin{array}{l}\text { Pendapatan Total petani/tahun } \\
\text { (Rp) }\end{array}$ & 28.141180 & 24.611 .794 & 16.741 .438 \\
\hline $\begin{array}{l}\text { Pendapatan Total diterima } \\
\text { petani/ bulan }(\mathrm{Rp})\end{array}$ & 2.345 .098 & 2.050 .983 & 1.395 .120 \\
\hline
\end{tabular}

Pada kemitraan yang dikelola oleh petani secara individual, karena produktivitasnya masih sangat rendah, yaitu hanya sebesar 11,8 ton/ha, maka penerimaan yang diperoleh pada kemitraan secara individual ini paling rendah, yaitu hanya sebesar Rp 14.561.407 per hektar. Sementara biaya per hektar yang dikelurakan petani paling besar yaitu mencapai Rp 10.799.286 per hektar, sehingga margin keuntungan yang diperoleh oleh petani relatif kecil, yaitu hanya sebesar $25,84 \%$.

Pendapatan petani pada model kemitraan yang dikelola oleh koperasi berasal dari laba operasional setelah dikurangi biaya managemen koperasi (fee) sebesar $4 \%$. Sehingga pendapatan petani adalah sebesar 94\% dari laba operasi yaitu sebesar $\mathrm{Rp}$ 15.682.711 per hektar per tahun. Sementara pendapatan petani pada kemitraan yang dikelola oleh perusahaan inti berasal dari bagi hasil dari nilai penjualan TBS (penerimaan) sebesar 55\%, yaitu sebesar Rp 13.799 .548 per hektar, lebih rendah dibanding pendapatan petani pada kemitraan yang dikelola oleh koperasi.

Pendapatan petani pada kemitraan yang dikelola oleh petani secara individu berasal dari $100 \%$ laba operasi pada kebun yang diusahakannya, yaitu sebesar Rp 3.762.121 per hektar per tahun. Rendahnya pendapatan petani ini disebabkan oleh rendahnya produktivitas tanaman yang disebabkan oleh umur tanamannya yang masih muda.

Jika dilihat dari pendapatan total petani, tampak bahwa pendapatan petani pada model kemitraan yang dikelola oleh koperasi sebesar Rp 28.141.180 per tahun, atau sebesar Rp 2.345.098 per bulan, lebih tinggi dibanding pada model kemitraan yang dikelola oleh perusahaan inti sebesar Rp 24.611.794 per tahun atau sebesar Rp 2.050.982 per bulan.

\section{PENGELOLAAN RISIKO}

Banyak risiko yang dihadapi petani pekebun kelapa sawit, baik risiko teknis yang berkait dengan produksi, seperti serangan hama dan penyakit tanaman dan musim yang kurang baik, risiko hukum/ sosial seperti terjadi sengeketa lahan; risiko terhadap ketersediaan pasokan input; dan risko pemasaran. Masing-masing model kemitraan memiliki perbedaan dalam pengelolaan risiko, seperti terdiskripsi pada Tabel 3. 
Tabel 3. Pengelolaan Risiko pada Masing-masing Model Kemitraan Perkebunan Kelapa Sawit Rakyat di Provinsi Kalimantan Tengah 2014

\begin{tabular}{|c|c|c|c|}
\hline Risiko & $\begin{array}{c}\text { Kemitraan Dikelola oleh } \\
\text { Koperasi }\end{array}$ & $\begin{array}{l}\text { Kemitraan Dikelola } \\
\text { oleh Perusahaan Inti }\end{array}$ & $\begin{array}{l}\text { Kemitraan Dikelola } \\
\text { oleh Petani Individual }\end{array}$ \\
\hline Produksi & $\begin{array}{l}\text { Satu unit produksi } \\
\text { berdasarkan kontribusi } \\
\text { lahan anggota, bukan } \\
\text { berdasarkan jumlah } \\
\text { produksi yang dicapai. } \\
\text { Model ini membagi risiko } \\
\text { produksi ke semua anggota } \\
\text { koperasi }\end{array}$ & $\begin{array}{l}\text { Risiko produksi ada } \\
\text { pada pihak } \\
\text { perusahaan, tetapi } \\
\text { sebenarnya juga } \\
\text { menjadi risiko petani, } \\
\text { karena besarnya } \\
\text { pendapatan petani } \\
\text { tergantung dari } \\
\text { besarnya produksi } \\
\text { yang dihasilkan oleh } \\
\text { perusahaan. }\end{array}$ & $\begin{array}{l}\text { Tanggung jawab dan } \\
\text { risiko melekat pada } \\
\text { masing-masing petani. } \\
\text { Petani sangat riskan } \\
\text { apabila terjadi risiko } \\
\text { eksternal seperti } \\
\text { kebakaran, dan serangan } \\
\text { hama atau penyakit. }\end{array}$ \\
\hline Hukum & $\begin{array}{l}\text { Risiko terbagi sebagai } \\
\text { sebuah grup. Koperasi } \\
\text { menghadapi sengketa pada } \\
\text { lahan saat ini, sehingga } 12 \\
\text { ha lahan menjadi tidak } \\
\text { produktif hingga kasus } \\
\text { hukum terselesaikan }\end{array}$ & $\begin{array}{l}\text { Tanpa sertifikat kepe- } \\
\text { milikan tanah yang } \\
\text { sah (hanya SKT), } \\
\text { petani menjadi rentan } \\
\text { terhadap risiko } \\
\text { hokum }\end{array}$ & $\begin{array}{l}\text { Risiko hukum } \\
\text { ditanggung oleh masing- } \\
\text { masing individu petani. } \\
\text { Selama penelitian tidak } \\
\text { ditemukan sengketa } \\
\text { lahan, namun potensi } \\
\text { terjadi sengketa sangat } \\
\text { mungkin terjadi. }\end{array}$ \\
\hline $\begin{array}{l}\text { Pasokan } \\
\text { (supply } \\
\text { input) }\end{array}$ & $\begin{array}{l}\text { Distribusi pupuk bersubsidi } \\
\text { tidak dapat diandalkan di } \\
\text { wilayah ini. Namun, dengan } \\
\text { total pembelian yang cukup } \\
\text { besar, koperasi bekerja sama } \\
\text { dengan pemasok untuk } \\
\text { memasok pupuk dan saran } \\
\text { sarana produksi lainnya } \\
\text { secara berkelanjutan }\end{array}$ & $\begin{array}{l}\text { Tidak ada risiko } \\
\text { pasokan, perusahaan } \\
\text { inti bertanggung } \\
\text { jawab untuk } \\
\text { pengelolaan rantai } \\
\text { pasok dan perawatan } \\
\text { kebun }\end{array}$ & $\begin{array}{l}\text { Pasokan input dijamin } \\
\text { oleh perusahaan inti; } \\
\text { para petani bahkan } \\
\text { dapat mencicil } \\
\text { pembayaran sampai } \\
\text { masa panen berikutnya. }\end{array}$ \\
\hline Pemasaran & $\begin{array}{l}\text { Perusahaan inti akan } \\
\text { menjamin off-take produksi } \\
\text { TBS. Namun, fluktuasi } \\
\text { harga TBS akan } \\
\text { mengganggu cadangan } \\
\text { dana koperasi }\end{array}$ & $\begin{array}{l}\text { Meskipun terdapat } \\
\text { perjanjian off-take, } \\
\text { pendapatan petani } \\
\text { tetap sangat sensitif } \\
\text { terhadap fluktuasi } \\
\text { harga TBS. }\end{array}$ & $\begin{array}{l}\text { Pendapatan petani tetap } \\
\text { sensitif terhadap } \\
\text { fluktuasi harga TBS. }\end{array}$ \\
\hline
\end{tabular}

Pada Tabel 3 terlihat bahwa dalam hal risiko produksi, pada kemitraan yang dikelola oleh koperasi, risiko bila terjadi kegagalan produksi ditanggung bersama oleh anggota koperasi. Bahkan ketika terjadi risiko produksi yang ekstrim, koperasi masih tetap memberikan pendapatan minimal kepada petani dari dana cadangan yang ada pada koperasi.

Pada kemitraan yang dikelola oleh perusahaan inti, karena petani tidak terlibat langsung dalam pengelolaa kebunnya, maka seolah-olah risiko kegalan produksi berada pada perusahaan inti, akan tetapi karena pendapat petani tergantung dari besarnya produksi yang dihasilkan, yaitu sebesar 55\% dari nilai penjualan, maka risiko kegalan produksi tersebut sebenarnya juga menjadi risiko petani.

Pada kemitraan yang dikelola oleh petani secara individu, risiko bila terjadi kegagalan produksi ditanggung oleh petani sendiri. Sementara belum ada perusahaan asuransi yang mau menjamin kegagalan usaha pada perkebunan kelapa sawit rakyat di daerah ini.

Risiko hukum, khususnya yang berkait dengan sengketa kepemilikan dan penguasaan lahan di Provinsi Kalimantan 
Tengah sangat besar potensinya, baik antara masyarakat setempat dengan perusahaan, maupun antar masyarakat sendiri. Hal ini disebabkan oleh tingginya laju perkembangan perkebunan kelapa sawit di daerah ini, baik perkebunan besar maupun perkebunan rakyat. Sementara masyarakat setempat pada umumnya tidak memiliki setifikat kepemilikan lahan yang dianggap sah secara hukum, melainkan hanya berupa Surat Keterangan Tanah (SKT) yang dikeluarkan oleh pemimpin masyarakat adat (demang atau mantir adat) maupun oleh kepala desa.

Pada kemitraan yang dikelola oleh koperasi, risiko hukum ditanggung bersama oleh seluruh anggota. Pada saat dilakukan penelitian terdapat lahan sengketa yang dikelola oleh koperasi seluas 12 ha sebagaimana diuraikan terdahulu, sehingga lahan yang berstatus sengketa tersebut dikeluarkan dari pengelolaan koperasi sampai kasusnya terselesaikan, yang berakibat rata-rata luas lahan per petani yang seharusnya seluas 2,0 ha, menjadi seluas 1,98 ha.

Pada kemitraan yang dikelola oleh perusahaan inti, tanpa sertifikat kepemilikan lahan yang jelas (hanya SKT), petani menjadi rentan terhadap risiko hukum. Sementara pada kemitraan yang dikelola oleh petani secara individu risiko hukum ditanggung oleh masing-masing individu petani.

Pasokan input (sarana produksi pertanian) secara umum bukan merupakan kendala bagi petani perkebunan kelapa sawit yang tergabung dalam model kemitraan di daerah ini. Pada kemitraan yang dikelola oleh koperasi, untuk menjamin kontinuitas pasokan sarana produksi pertanian, koperasi menjalin kerjasama dengan pengusaha pemasok setempat. Sementara untuk kemitraan yang dikelola oleh perusahaan inti maupun kemitraan individual, pasokan sarana produksi dijamin oleh perusahaan inti.

Pemasaran hasil juga bukan merupakan risiko besar bagi semua model kemitraan yang ada, karena ada jaminan penampungan hasil oleh perusahaan inti.

\section{KESIMPULAN DAN SARAN}

\section{KESIMPULAN}

Dari penelitian ini disimpukan bahwa model kemitraan inti-plasma yang dikelola oleh koperasi (model I) merupakan model terbaik, dengan indikator sebagai berikut:

1. Produktivias tanaman paling tinggi, ratarata mencapai 20,0 ton TBS/ha/tahun, lebih tinggi dibanding model II sebesar 18,0 ton dan model III sebesar 11,8 ton;

2. Pendapatan petani/ha/tahun paling tinggi, yaitu sebesar Rp 15.682.711, dibanding model II sebesar Rp 13.799.548 dan model III sebesar Rp 3.762.121;

3. Risiko usaha ditanggung bersama oleh seluruh anggota koperasi;

4. Ada jaminan rantai pasok (supply chain) dan pemasaran hasil melalui kerjasama dengan perusahaan inti;

5. Petani masih mempunyai peluang untuk memperoleh pendapatan lain sebagai pekerja di perusahaan perkebunan atau koperasi atau kegiatan usaha lainnya.

\section{SARAN}

Dalam rangka untuk mengembangkan perkebunan kelapa sawit rakyat di Provinsi Kalimantan Tengah, disarankan kepada Pemerintah Provinsi sebagai berikut:

1. Berkait dengan kewajiban perusahaan perkebunan Swasta (PBS) untuk membangun kebun plasma minimal 20\%, agar pembangunan kebun plasma tersebut diimplementasikan dalam model kemitraan inti-plasma melalui koperasi.

2. Kementerian Pertanian dan UNDP akan bekerjasama menerapkan ISPO khusunya untuk perkebunan kelapa sawit rakyat swadaya melelui Proyek Inisiatif Perkebunan Kelapa Sawit Berkelanjutan/ Sustainable Palm Oil Initiative (Direktorat Jenderal Perkebunan, 2015). Untuk itu, khususnya dalam rangka pembinaan dan pengembangan perkebunan kelapa sawit rakyat swadaya yang pada umumnya mengusahakan perkebunannya secara sendiri-sendiri, tidak tergabung dalam 
kelompok tani maupun koperasi, agar para petani tersebut mulai dibina untuk berusaha secara berkelompok melalui kelompok tani dan membentuk koperasi, karena sertifikasi ISPO hanya akan diberikan kepada petani melalui kelompok tani atau koperasi.

\section{DAFTAR PUSTAKA}

Badan Pusat Statistik. 2014. Statistik Perkebunan Kelapa Sawit. Jakarta.

BPS Provinsi Kalimantan Tengah. 2013. Produk Domestik Regional Bruto Provinsi Kalimantan Tengah Tahun 2012. Palangka Raya.

Dinas Perkebunan Provinsi Kalimantan Tengah. 2014. Statistik Perkebunan Provinsi Kalimantan Tengah Tahun 2013. Palangka Raya.

Direktorat Jenderal Perkebunan. 2015. Inisiatif Kelapa Sawit Berkelanjutan/ Sustainable Palm Oil Initiative. Makalah bahan diskusi pada Pertemuan Working Group Inisiatif Kelapa Sawit Berkelanjutan di Kementerian Pertanian tanggal 10-11 Maret 2015. Jakarta.

Institut Pertanian Bogor. 2012. Reducing Agricultural Expansion Into Forests in Central Kalimantan-Indonesia: Analysis of Implementation and Financing Gaps. Bogor.

Yahya, Sudirman dan Basyaruddin, Darmansyah. 2015. Peningkatan Kapasitas Petani. Makalah bahan diskusi pada Pertemuan Working Group Inisiatif Kelapa Sawit Berkelanjutan di Kementerian Pertanian tanggal 10-11 Maret 2015. Jakarta. 
Lampiran 1. Hubungan Kemitraan Perkebunan Kelapa Sawit Rakyat yang Dikelola oleh Koperasi

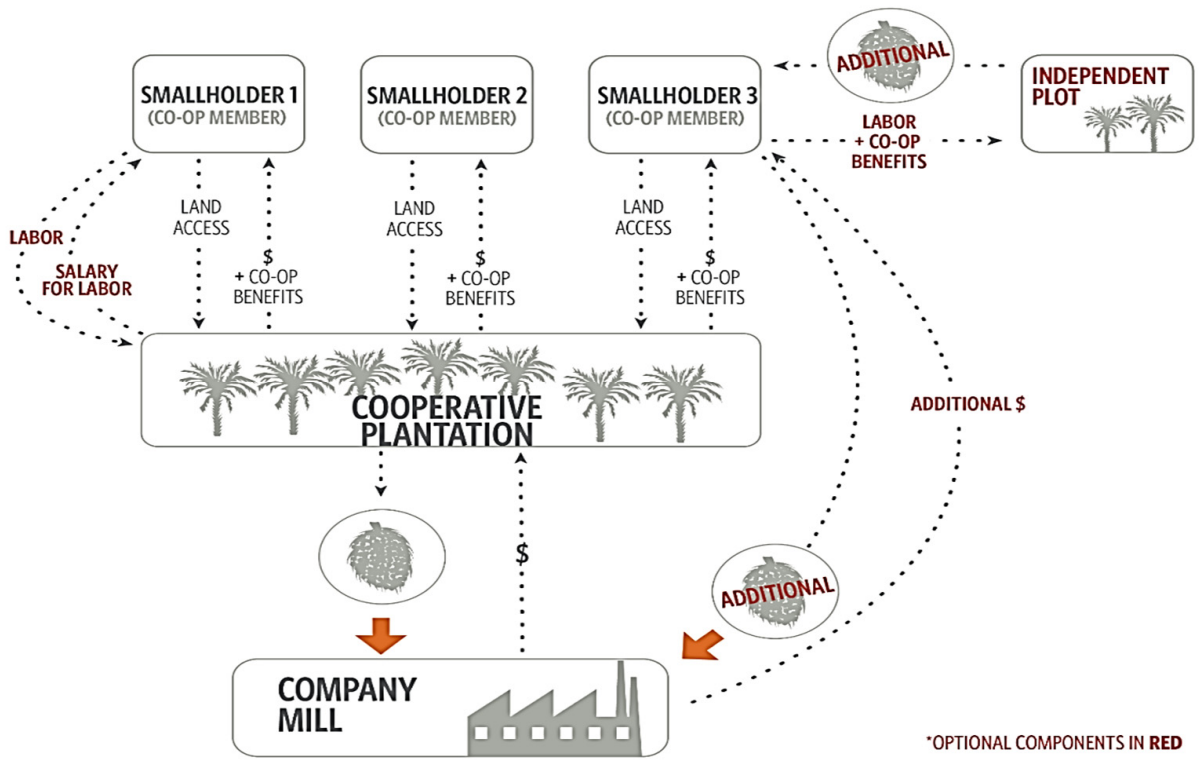

Lampiran 2. Hubungan Kemitraan Perkebunan Kelapa Sawit Rakyat yang Dikelola oleh Perusahaan Inti

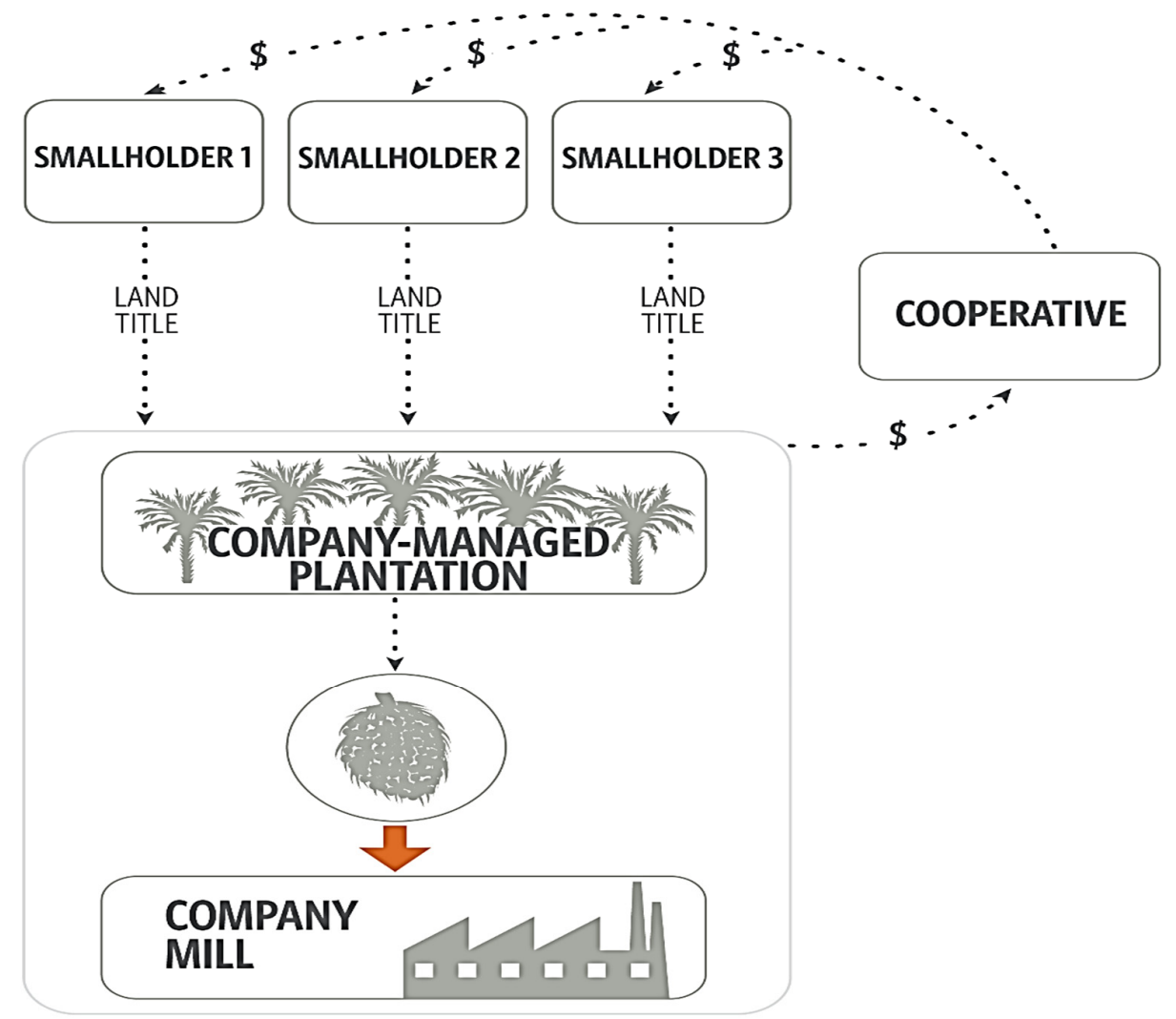


Lampiran 3. Hubungan Kemitraan Perkebunan Kelapa Sawit Rakyat yang Dikelola oleh Petani Individual

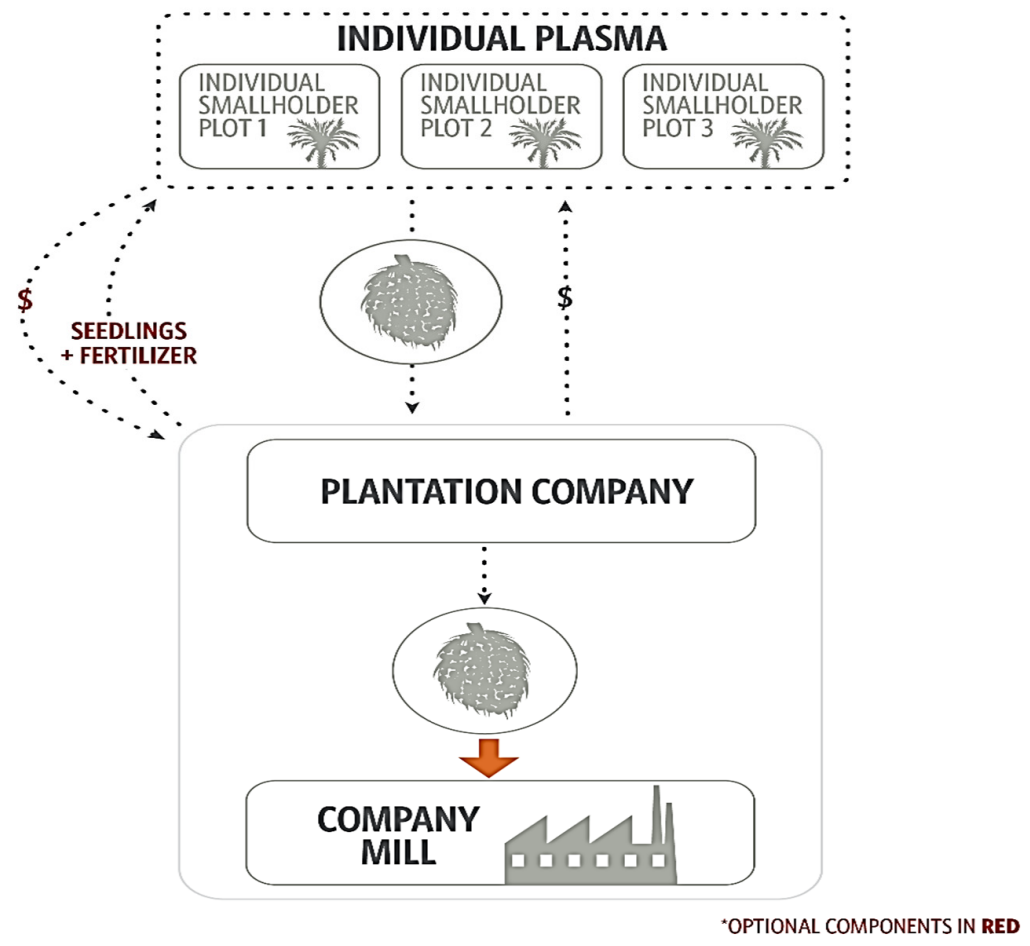

